\title{
Erratum to: Preimplantation factor (PIF) analog prevents type I diabetes mellitus (TIDM) development by preserving pancreatic function in NOD mice
}

\author{
Lola Weiss - Steve Bernstein - Richard Jones - Ravi Amunugama • \\ David Krizman • Lellean JeBailey • Osnat Almogi-Hazan • \\ Zhanna Yekhtin - Reut Shainer - Israel Reibstein · Elizabeth Triche • \\ Shimon Slavin · Reuven Or · Eytan R. Barnea
}

Published online: 12 April 2011

(C) Springer Science+Business Media, LLC 2011

\section{Erratum to: Endocr}

DOI 10.1007/s12020-011-9438-5

In the original publication, the names of the seventh, eighth, and ninth authors are misspelled. The correct

The online version of the original article can be found under doi: 10.1007/s12020-011-9438-5.

L. Weiss · O. Almogi-Hazan · Z. Yekhtin - R. Shainer · I. Reibstein · R. Or

Department of Bone Marrow Transplantation and Cancer Immunotherapy, Hadassah University Hospital Ein Kerem,

Hebrew University, Jerusalem, Israel

S. Bernstein

QualTek Molecular Laboratories, Santa Barbara, CA, USA

R. Jones · R. Amunugama

NextGen Sciences Ltd., Ann Arbor, MI, USA

D. Krizman

Expression Pathology, Inc., Gaithersburg, MD, USA

L. JeBailey

GeneGo Inc., St. Joseph, MI, USA

S. Slavin International Center for Cell Therapy \& Cancer Immunotherapy (CTCI), Tel Aviv, Israel spellings are Osnat Almogi-Hazan, Zhanna Yekhtin, and Reut Shainer.

\section{E. Triche}

Department of Community Health and Epidemiology, Brown

University School of Medicine, Providence, RI, USA

E. R. Barnea $(\square)$

The Society for the Investigation of Early Pregnancy (SIEP), 1697 Lark Lane, Cherry Hill, NJ 08003, USA

e-mail: barnea@earlypregnancy.org

E. R. Barnea

Department of Obstetrics and Gynecology, University of Medicine and Dentistry of New Jersey, Robert Wood Johnson Medical School, Camden, NJ, USA 